\title{
AGRICULTURAL SUPPORT POLICY AS A DETERMINANT OF INTERNATIONAL COMPETITIVENESS: EVIDENCE FROM THE EU AND US
}

\author{
Karolina Pawlak ${ }^{1}$, PhD habilitated, assoc. prof. \\ ${ }^{1}$ Poznan University of Life Sciences, Poland
}

\begin{abstract}
Government policies are more important and pervasive than natural endowments in determining competitiveness of agri-food sector. One of the most important policy areas are agricultural policies. The aim of this paper is to identify the differences in levels and structures of support for agricultural producers in the EU and US over the 1986-2016 period. The study relies on data retrieved from the "Producer and Consumer Support Estimates Database" of the OECD. The following indicators of agricultural support were used: TSE, \% TSE, PSE, \% PSE, MPS, GSSE, TCT, NAC and NPC. Both the EU and the US still heavily support their agricultural sectors. However, positive developments took place in the structure of support which means a gradual substitution of price support measures with payments having less distortive effects on market and trade processes. Irrespective of changes to the nature of support, which have already taken place, it may be assumed that in the economies considered, there is still a potential to introduce less trade distorting and more market oriented policies. The EU provides the agricultural producers with twice as much support (measured with the \% PSE index) as the US, and the EU market is covered by stronger customs protection measures. Having this in mind, it may be assumed that in the context of potential liberalization of the EU-US bilateral trade (and/or world trade) and the progressive reduction of support for the domestic agricultural sector, the expected trade creation effect (stronger in the US than in the EU) could drive the strengthening of the US international competitive position.
\end{abstract}

Key words: agricultural producer support, international competitiveness, the EU, the US. JEL code: E64, Q18.

\section{Introduction}

The EU and the US are the largest players of world trade in agri-food products. In 2016, the value of agri-food exports from the EU and from the US was USD 521.4 billion and USD 135.6 billion, respectively, representing nearly $38 \%$ and $10 \%$ of world exports (UNCTADstat, 2018). However, considering that the Single European Market (SEM) ${ }^{1}$ represents almost $3 / 4$ of the EU's trade flows, and taking account only of trade volumes with non-EU countries (USD 137.5 billion in 2016), the shares of the countries considered in the global food trade were at a nearly equal level of around $10 \%$. On one hand, despite a relatively small value of bilateral trade, the EU and US are important trade partners (Pawlak K., 2017), but on the other, they compete with each other.

According to Bienkowski (1995), the macroeconomic determinants of international competitive capacity include the national socio-economic system and government policy, next to the size, quality, structure and efficiency of owned production resources and the ability to impact the international economic environment. The importance of the government policy for the development of competitive advantages of the agri-food sector is also noted by Dunmore (1986), Brinkman (1987), Harrison and Kennedy (1997), Van Duren, Martin and Westgren (1991)2, Abbott and Bredahl (1994), and Prus and Drzazdzynska (2017). As emphasized by Dunmore (1986), government policies are more important and pervasive than natural endowments in determining competitiveness and comparative advantage, especially in the longer term, when they become the source of the "dynamics" of comparative advantage. According to the author, the three most important policy areas are: domestic macroeconomic policies, domestic farm policies, and foreign

\footnotetext{
${ }^{1}$ The high share of intra-EU flows in the EU's agricultural exports is primarily determined by geographic proximity of EU states and absence of mutual trade barriers. That trade pattern is also largely affected by similar dietary habits and food marketing systems (Reed M.R., 2001).

2 According to Van Duren, Martin and Westgren (1991), the government's impact on the business environment with various types of policies is

equivalent to factors controlled by government or, in other words, factors beyond the control of competing firms (Reiljan J., Hinrikus M., Ivanov A., 2000). 
trade and agricultural policies (Dunmore J. C., 1986). Abbott and Bredahl (1994) also pay considerable attention to trade and agricultural policies as the determinants of international competitiveness of the agri-food sector. In the context of the on-going rivalry in the international agricultural market, and considering the agricultural policy as a primary determinant of competitiveness of the agri-food sector, it is necessary to ask the question about the level and structure of agricultural support in the countries playing the key role in world trade. Therefore, the aim of this paper is to identify the differences in levels and structures of support for agricultural producers in the EU and US over the 1986-2016 period.

\section{Data and research methods}

This study relies on data retrieved from the "Producer and Consumer Support Estimates Database" of the Organization for Economic Cooperation and Development (OECD). The purpose of indicators published in the Database is to assess the impact of agricultural and trade policy measures on agricultural producers and food consumers. Both the budget transfers allocated to individual producers and the payments to the agricultural sector as a whole are covered by the indicators. The support resulting from the operation of tools which lead to a price gap between the domestic and global market is also included in (Poczta-Wajda A., 2017). Published annually, these indicators are the only internationally comparable, complete and widely available source of information about agricultural support levels in developed countries ${ }^{1}$ (Poczta-Wajda A., 2013).

This paper uses the following available indicators (OECD, 2016; OECD, 2017):

- Total Support Estimate (TSE) - the annual monetary value of all gross transfers from taxpayers and consumers arising from policy measures that support agriculture. It is calculated as the sum of Producer Support Estimate (PSE), General Services Support Estimate (GSSE), and Transfers to Consumers from Taxpayers (TCT). For reasons of comparability between countries, the Percentage TSE ( \% TSE) is calculated which shows TSE transfers as a percentage of GDP;

- Producer Support Estimate (PSE) - the annual monetary value of gross transfers from consumers and taxpayers to agricultural producers, measured at the farm gate level, arising from policy measures that support agriculture. It includes Market Price Support (MPS); payments based on inputs use; payments based on current or non-current area planted, animal numbers, farm receipts or farm income (production required or not required); and other transfers. For reasons of comparability between countries, the percentage PSE ( \% PSE) is calculated which refers to PSE transfers as a share of gross farm receipts;

- Market Price Support (MPS) - the annual monetary value of gross transfers from consumers and taxpayers to agricultural producers arising from policy measures that create a gap between domestic market prices and border prices of a specific agricultural commodity, measured at the farm gate level;

- General Services Support Estimate (GSSE) - the annual monetary value of gross transfers to general services provided to agricultural producers collectively (such as agricultural knowledge and innovation system, inspection and control, development and maintenance of infrastructure, marketing and promotion, cost of public stockholding and miscellaneous items), arising from policies that support agriculture. The GSSE does not include any transfers to individual producers;

\footnotetext{
${ }^{1}$ Since 1986, support indicators have been calculated each year for all OECD member countries, including EU countries considered globally. Also, since 1995, OECD has consistently extended the subjective scope of its statistics with non-member countries, including developing countries. There are: Brazil, Colombia, China, Costa Rica, Indonesia, Kazakhstan, Philippines, Russia, South Africa, Ukraine, and Viet Nam.
} 
- Transfers to Consumers from Taxpayers (TCT) - the annual budgetary payments to consumers that are given for the specific purpose of compensating them for the higher prices they pay for agricultural products that result from policies that support producer prices. The TCT is obtained from the information on budgetary expenditures;

- Producer Nominal Assistance Coefficient (NAC) - the ratio between the value of gross farm receipts (including support) and gross farm receipts valued at border prices (measured at farm gate). It specifies how many times more do farmers earn than they would without state intervention;

- Producer Nominal Protection Coefficient (NPC) - the ratio between the average price received by producers at farm gate (including payments per tonne of current output and excluding price levies based on output) and the border price (measured at farm gate). It measures the distortion of domestic prices.

The timeframes of this study were determined by the availability of data, extending from 1986 to 2016, split into three three-year periods: 1986-1988, 1995-1997 (first years of implementing the Agreement on Agriculture entered into under the GATT/WTO Uruguay Round Final Act whose assumptions included limiting the levels and increasing discipline in the use of domestic support measures for the agriculture, while providing the countries with a broad range of support measures that take account of specific conditions of agricultural production), and 2014-2016.

\section{Research results and discussion}

The TSE is the OECD's broadest indicator of agricultural support. Over the past decades, both the US and the EU have provided substantial government support for their agricultural sectors. In absolute terms, from 2014 to 2016, the total costs incurred by the society to finance agricultural support in EU countries was USD 115.9 billion, on average, representing $36 \%$ of total transfers allocated for that purpose in OECD countries (Table 1). In the US, the average annual value of transfers to the agricultural sector and agricultural producers was by nearly $1 / 4$ smaller (USD 88.4 billion) than in the EU in that period. However, at the same time, it was more than $80 \%$ higher than agricultural support allocated in 1986-1988. An important insight is provided by the analysis of TSE expressed as a percentage value. Despite the growth of support delivered to the agricultural sector and producers in absolute terms, the overall burden of agricultural support on the EU and US economies has declined since the mid-1980s, as measured by total support as percentage of GDP. In the EU countries (considered as a union between 28 Member States), the total agricultural support went down from $2.6 \%$ of GDP in 1986-1988 to $0.7 \%$ of GDP in 2014-2016 whereas in the US, the share of transfers to the agricultural sector and agricultural producers in GDP declined from $1.0 \%$ to $0.5 \%$ over the same period. But public policy support continues to be important for the agricultural sectors of the EU and USA. In those countries, the ratio of TSE to the total production value (at farm gate) was around $31 \%$ and $23 \%$, respectively, compared to $27 \%$ in the OECD countries. The ratio between TSE and agricultural value added in both economies under consideration was close to the OECD average of $39 \%$ (OECD, 2017).

In the EU, policy transfers to individual producers (PSE) are the major component of total support. In the EU, throughout the study period, the share of PSE in the total value of monetary transfers from taxpayers and consumers to the agricultural sector and agricultural producers remained at a level of around $88 \%$; in 2014-2016, it was twice higher than in the US (43\%; Table 2). It should be noted that 1986-2016 was a period of considerable evolution in the structure 
of financial support for the US agricultural sector. The importance of gross monetary transfers from taxpayers and consumers to agricultural producers declined by 30 percentage points. This was accompanied by the growing importance of mechanisms supporting the demand for foodstuffs (TCT), which also provide indirect support to agricultural producers. That indicator went up from $21 \%$ in $1986-1988$ to $47 \%$ in $2014-2016$. In this respect, the US follow a globally unique policy for the support of the agricultural sector and agricultural producers. In 2014-2016, according to OECD data, the average value of food aid schemes (which is approximated by TCT) was by nearly USD 3.0 billion higher than the value of agricultural producers support measured with PSE. In that period, the value of support delivered to US agricultural producers (PSE) was USD 38.4 billion, whereas USD 41.3 billion were allocated to national food aid schemes (TCT). Meanwhile, in the EU, the level of measures designed to support food consumption was almost USD 1.2 billion, compared to USD 101.8 billion allocated to transfers for agricultural producers (Producer and Consumer Support Estimates Database, 2018). Therefore, it may be assumed that PSE is not fully reliable in the case of the US, as it fails to take account of measures designed to support food consumption which exceed the value of support allocated to agricultural producers. In the economies considered, the importance of total transfers allocated to the sector (GSSE) was comparable throughout the study period, representing 10-11 \% of total support ${ }^{1}$ in 2014-2016 (Table 2).

Table 1

Support to agriculture in the OECD countries, EU and US in 1986-2016

\begin{tabular}{|l|c|c|c|c|c|c|c|c|c|}
\hline \multirow{2}{*}{ Specification } & \multicolumn{3}{|c|}{$1986-1988$} & \multicolumn{3}{c|}{$1995-1997$} & \multicolumn{3}{c|}{$2014-2016$} \\
\cline { 2 - 11 } & OECD & EU & US & OECD & EU & US & OECD & EU & US \\
\hline $\begin{array}{l}\text { TSE } \\
\text { (million USD) }\end{array}$ & 258 & 111 & 48 & 319 & 132 & 48 & 319 & 115 & 88 \\
\hline TSE \% & 2.40 & 2.60 & 1.00 & 1.40 & 1.40 & 0.60 & 0.60 & 0.70 & 0.50 \\
\hline PSE \% & 36.50 & 39.20 & 21.20 & 30.40 & 33.80 & 11.90 & 18.20 & 19.60 & 9.50 \\
\hline NAC & 1.57 & 1.64 & 1.27 & 1.44 & 1.51 & 1.14 & 1.22 & 1.24 & 1.10 \\
\hline NPC & 1.51 & 1.69 & 1.12 & 1.31 & 1.33 & 1.06 & 1.10 & 1.05 & 1.03 \\
\hline
\end{tabular}

Source: author's calculations based on Producer and Consumer Support Estimates Database (2018)

Table 2

\section{Composition of the Total Support Estimate in the EU and US in 1986-2016 (\%)}

\begin{tabular}{|l|c|c|c|c|c|c|}
\hline \multirow{2}{*}{ Specification } & \multicolumn{2}{|c|}{$\mathbf{1 9 8 6 - 1 9 8 8}$} & \multicolumn{2}{c|}{$\mathbf{1 9 9 5 - 1 9 9 7}$} & \multicolumn{2}{c|}{$\mathbf{2 0 1 4 - 2 0 1 6}$} \\
\cline { 2 - 7 } & EU & US & EU & US & EU & US \\
\hline TSE, including: & 100.0 & 100.0 & 100.0 & 100.0 & 100.0 & 100.0 \\
\hline PSE & 87.3 & 72.8 & 88.2 & 53.0 & 87.9 & 43.4 \\
\hline GSSE & 8.2 & 6.4 & 8.1 & 8.8 & 11.1 & 9.9 \\
\hline TCT & 4.5 & 20.8 & 3.7 & 38.2 & 1.0 & 46.7 \\
\hline
\end{tabular}

Source: author's calculations based on Producer and Consumer Support Estimates Database (2018)

One of the most widely adopted indicators of agricultural support is PSE expressed as a percentage ratio of financial support to the total receipts of agricultural producers. In EU countries and in the US, the levels of agricultural producers support have considerably declined over the last 30 years, from $39.2 \%$ to $19.6 \%$ in the EU and from $21.2 \%$ to $9.5 \%$ of the agricultural producers' receipts in the US' (Table 1). Unlike in the US, the EU witnessed a stronger decrease in

\footnotetext{
${ }_{1}^{1}$ For a broader discussion on the levels and structure of support for services provided to agricultural producers collectively in countries at various levels of economical development, including the EU and US, see Kulyk (2013).

2 Note that support for the US agricultural producers, measured with \%PSE, fluctuates strongly because many of the local measures are of an anticyclical nature and are increasingly used when prices drop in the global market. This was the case, for instance, in 1999 where the \%PSE reached nearly $36 \%$ (Producer and Consumer Support Estimates Database, 2018). 
the PSE percentage ratio after 1995, with the most intense downward trend being observed in 2002-2016. In that period, the level of support for agricultural producers dropped by nearly 13.5 percentage points (Figure 1). It is worth noting that although the Agreement on Agriculture requires the signatories to restrict their support measures, the levels of \% PSE did not significantly change in the EU upon completion of the implementation period (1995-2000 in the developed countries). On the contrary, a slight growth was experienced in the US. In 2000, the \% PSE ratio in the EU and US was $33.2 \%$ and $22.7 \%$, respectively, which is 6 percentage points less and 1.4 percentage points more than the average levels recorded in 1986-1988 (the reference period for support reduction). The underlying reason could be the division of support measures into three boxes: the green box, blue box and amber box. The restrictions implemented under WTO agreements would only be applicable to amber box instruments which directly impact the production and considerably distort market processes (support measured with AMS, the Aggregate Measurement of Support). Meanwhile, PSE covers a broader scope of support measures classed in all three boxes as well as de minimis payments (Poczta-Wajda A., 2013).

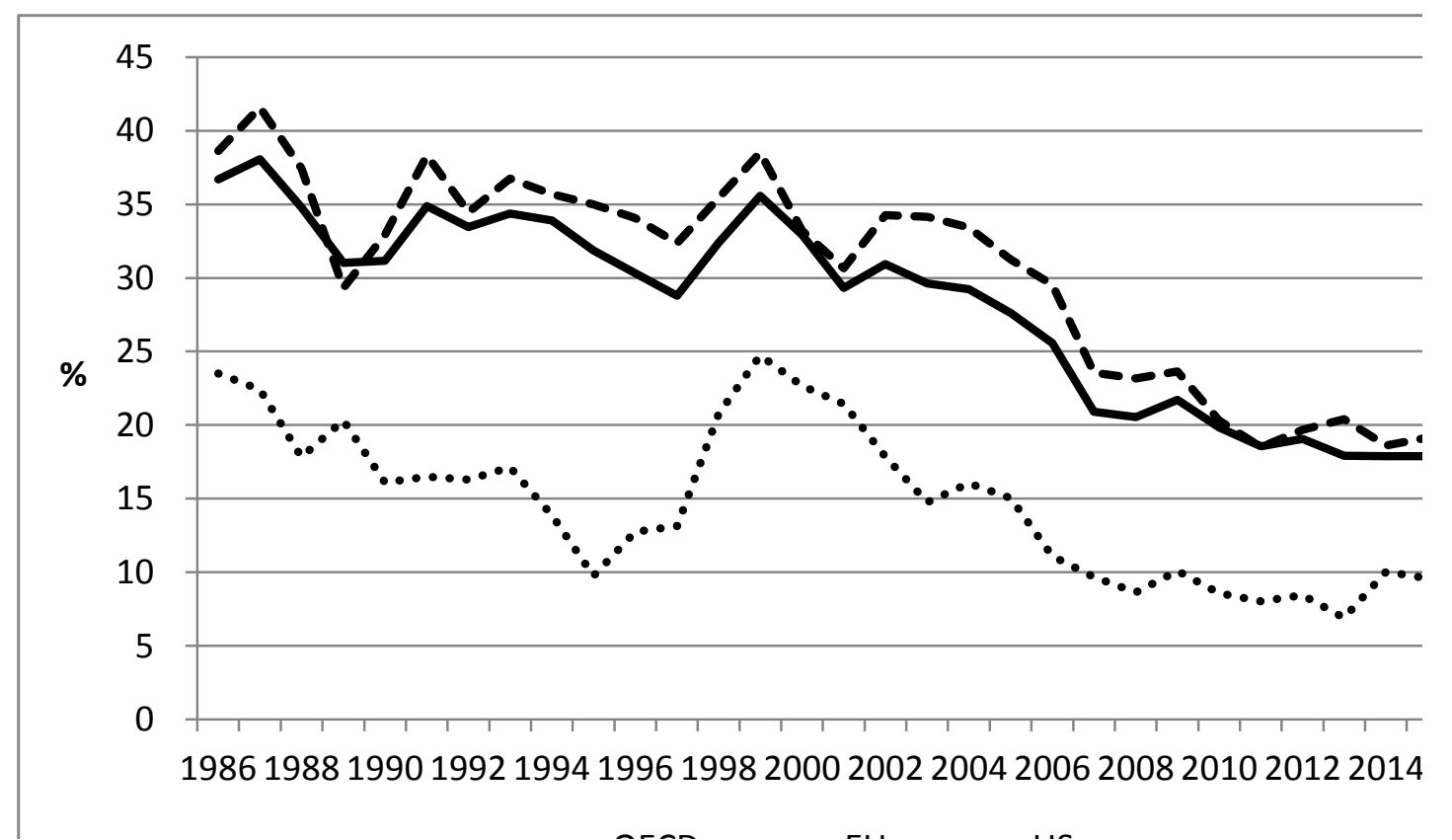

Source: author's calculations based on Producer añ Cónsumer Suppört Estimates 'Database (2018)

Fig. 1. Evolution of Producer Support Estimate in 1986-2016 (percentage of gross farm receipts)

This fact is proven by the analysis of the structure of support for agricultural producers measured with PSE in the countries covered by this study (Table 3). In the EU, already during the implementation period of the Agreement on Agriculture (1995-1997), there was a considerable reduction of price support (MPS) classed in the amber box. Price support leads to a distortion of domestic prices and, in the case of countries with a high share in world exports (such as the EU and US), of global prices. In the EU, agricultural policy measures responsible for the gap between the price obtained by agricultural producers and the global price represented $85 \%$ and $57 \%$ of PSE in 1986-1988 and in 1995-1997, respectively. In the US, the level of price support in that period (44\% of PSE) was lower than in the EU. However, compared to the 1986-1988 reference period, it grew by 10 percentage points. Only in 2000, it reached $30.9 \%$ (Table 3; Producer and Consumer Support Estimates Database, 2018). In 2014-2016, the importance of agricultural policy measures characterized by MPS (considered to be the most distortionary for trade and market 
processes) was even lower, fluctuating around $20 \%$ and $27 \%$ in the EU and US, respectively. In turn, the instruments based on direct support of agricultural incomes grew in importance. Initially, in the EU, these were payments based on current area, animal numbers, farm receipts or farm income by which production is required (with an average share in the PSE structure of $32 \%$ in 1995-1997), and subsequently payments based on non-current area, animal numbers, farm receipts or farm income by which production is not required (42\% of PSE on average in 2014-2016; Table 3). Changes observed in the structure of EU agricultural support reflected the two key CAP reforms from 1992 and 2003. First, compensatory payments were established as a part of MacSharry reforms. Afterwards, they were replaced by a new system of direct decoupled payments. In the 2014-2016 period, compared to levels recorded in 1995-1997, payments based on current area, animal numbers, farm receipts or farm income have been cut by almost two-thirds in favour of direct payments based on non-current criteria without production requirements (OECD, 2017). In the US, there was also a trend towards payments which are less coupled with production decisions. As regards support instruments with a less distorting effect on trade and market processes, the US also used payments based on input use in addition to the two instrument categories listed above. In 2014-2016, the US recorded a similar share of these three PSE components (at a level of 21-24\% of PSE; Table 3).

\section{Composition of the Producer Support Estimate in the EU and US} in 1986-2016 $(\%)$

\begin{tabular}{|l|c|c|c|c|c|c|}
\hline \multirow{2}{*}{ Specification } & \multicolumn{2}{|c|}{$\mathbf{1 9 8 6 - 1 9 8 8}$} & \multicolumn{2}{c|}{$\mathbf{1 9 9 5 - 1 9 9 7}$} & \multicolumn{2}{c|}{$\mathbf{2 0 1 4 - 2 0 1 6}$} \\
\cline { 2 - 7 } & EU & US & EU & US & EU & US \\
\hline PSE, including: & 100.0 & 100.0 & 100.0 & 100.0 & 100.0 & 100.0 \\
\hline MPS & 84.9 & 34.0 & 57.3 & 44.3 & 20.3 & 27.2 \\
\hline Payments based on input use & 5.2 & 20.0 & 7.0 & 25.9 & 13.4 & 21.9 \\
\hline $\begin{array}{l}\text { Payments based on current } \\
\text { A/An/R/I, production required }\end{array}$ & 3.6 & 34.6 & 31.6 & 7.1 & 21.6 & 20.6 \\
\hline $\begin{array}{c}\text { Payments based on non-current } \\
\text { A/An/R/I, production required }\end{array}$ & 0.0 & 0.0 & 0.0 & 0.0 & 0.1 & 0.0 \\
\hline $\begin{array}{c}\text { Payments based on non-current } \\
\text { A/An/R/I, production not } \\
\text { required }\end{array}$ & 0.0 & 1.0 & 0.0 & 14.9 & 42.0 & 24.3 \\
\hline \begin{tabular}{l} 
Others \\
\hline
\end{tabular} & 6.2 & 10.5 & 4.0 & 7.8 & 2.6 & 6.0 \\
\hline
\end{tabular}

A/An/R/I - Area planted, animal numbers, receipts/income

Source: author's calculations based on Producer and Consumer Support Estimates Database (2018)

The conclusions from the analysis of \%PSE levels and dynamics are supported by the Producer Nominal Assistance Coefficient (NAC) analysis. From 1986 to 2016, a strong decrease in the importance of financial support for the total receipts of agricultural producers was observed (in the US and the EU, it was more noticeable before and after 1995, respectively). Afterwards, in mid-2010s, the agricultural receipts in the EU and the US was (respectively) by nearly $25 \%$ and $10 \%$ higher than that the farmers would earn without state aid, compared to $65 \%$ and $27 \%$, respectively, in the 1986-1988 period (NAC coefficient; Table 1). The author has noted that despite the convergence of NAC coefficients in the study period, the financial instruments supporting the agricultural receipts were slightly more important in the EU than the average OECD level. However, both the EU countries and the US made greater use of instruments supporting the producers' incomes than of instruments distorting the price level in domestic markets (NAC>NPC). Moreover, the support went mainly to large producers, while the income of smaller farmers did not 
substantially improve (Swinnen J. et al., 2000; Olper A., 2001; Boulanger P., 2010; Anderson K. et al., 2013; Poczta-Wajda A., 2014). The NPC values compare prices received by countries' producers on average with those prevailing on world markets. It can be noticed that the level of price distortions was generally falling over the period 1986-2016, and prices received by producers both in the EU and US were more closely aligned with those prevailing on world markets, as countries provide a larger share of support through less distorting measures ${ }^{1}$. This was reflected by the decreasing share of price support (MPS) in the PSE structure of countries covered by this study (Table 3). For the EU countries, effective producer prices were, on average, $5 \%$ higher than the world market prices in 2014-2016, compared with around $70 \%$ higher in the mid-1980s (Table 1). The US have made a less substantial progress in aligning process. However, already in the 19861988 period, prices obtained by the US agricultural producers were only $12 \%$ higher, on average, than world prices. Finally, in 2014-2016, that gap reached $3 \%$. With an uneven scale of the converge process, the gap between domestic and world prices has narrowed in both analysed economies, meaning that market signals are becoming more important for producers' decisions (OECD, 2017).

\section{Conclusions, proposals, recommendations}

1) Over the past decades, both the US and the EU have provided substantial government support for their agricultural sectors. Although in 1986-2016 the overall burden of agricultural support on the EU and US economies has declined, as measured by total support as percentage of GDP, public policy support continues to be important for the agricultural sectors of the EU and US.

2) The declining levels of support for EU and US agricultural producers were also reflected by the decreasing values of \%PSE. Over the last 30 years, the share of financial support in total receipts of EU agricultural producers has considerably decreased, from $39.2 \%$ in 1986-1988 to $19.6 \%$ in 2014-2016. And yet, it was nearly twice as high as in the US (9.5\% in 2014-2016 compared to $21.2 \%$ in 1986-1988). However, it may be assumed that PSE is not fully reliable in the case of US, as it fails to take account of measures designed to support food consumption (TCT) which exceed the value of support allocated to agricultural producers. Therefore, it may be concluded that the US consumers thus become net beneficiaries of agricultural support programs whereas the burden of financial support for agricultural producers imposed on the EU consumers is usually heavier than what they receive in off-setting benefits.

3) In mid-2010s, the agricultural receipts in the EU and the US were (respectively) by nearly $25 \%$ and $10 \%$ higher than that the farmers would earn without state aid, compared to $65 \%$ and $27 \%$ (measured with the NAC coefficient), respectively, in the 1986-1988 period. However, in both economies covered by this analysis, the structure of support has undergone some positive developments: the price support measures have been gradually substituted with payments less distorting to the trade and market processes. As a consequence, prices in domestic markets of these countries have moved ever closer to the world price level. Irrespective of changes to the nature of support which have already taken place, it may be assumed that in the economies considered, there is still a potential to introduce less trade-distorting and more market-oriented policies.

4) Higher levels of support for EU agricultural producers are accompanied by higher levels of customs protection of the EU market. Having the above in mind, it may be supposed that (in the

${ }^{1}$ Some authors, however, doubt the effectiveness of these reforms (Cf. e.g. Tangermann S., 2004). 
context of the potential resumption of negotiations intended to deepen the transatlantic economic ties and/or to overcome the impasse in multilateral WTO negotiations) the US, expecting a stronger export-driving effect on the economy than in the EU, would be the ones to press harder for an extensive liberalization of trade and for a progressive reduction of domestic support for the agricultural sector. This is because the expected trade creation effects, stronger than in the EU, may drive the strengthening of the US competitive position in bilateral and global trade.

\section{Acknowledgments}

The paper is funded by National Science Centre within the OPUS research project No. 2015/17/B/HS4/00262, titled "Polish agri-food sector under the implementation of the Transatlantic Trade and Investment Partnership agreement (TTIP)".

\section{Bibliography}

1. Abbott, P.C., Bredahl, M.E. (1994). Competitiveness: Definitions, Useful Concepts and Issues. In: Competitiveness in International Food Markets, M.E. Bredahl, P.C. Abbott, M.R. Reed (eds.). Westview Press, Boulder, San Francisco, Oxford, pp. 11-35.

2. Anderson, K., Croser, J., Sandri, D., Valenzuela, E. (2013). Agricultural Distortion Patterns since the 1950s: What Needs Explaining? In: The Political Economy of Agricultural Price Distortions, K. Anderson (ed.). Cambridge University Press, New York, pp. 25-80.

3. Bienkowski, W. (1995). Reaganomika i jej wplyw na konkurencyjnosc gospodarki amerykanskiej (Reaganomics and its impact on the competitiveness of the US economy). Wydawnictwo Naukowe PWN, Warszawa, pp. 22-23.

4. Boulanger, p. (2010). Distribution of Agricultural Support: Selected French Evidences. Groupe d'Economie Mondiale (GEM), SciencesPo, OECD, Paris, pp. 55.

5. Brinkman, G.L. (1987): The Competitive Position of Canadian Agriculture. Canadian Journal of Agricultural Economics, Volume 35, Issue 2, pp. 263-288.

6. Dunmore, J.C. (1986): Competitiveness and Comparative Advantage of U.S. Agriculture. Paper presented at the 1986 National Public Policy Education Conference, Denver, Colorado, 16 September 1986, pp. 31.

7. Harrison, R.W., Kennedy, P.L. (1997). A Neoclassical Economic and Strategic Management Approach to Evaluating Global Agribusiness Competitiveness. Competitiveness Review, Volume 7, Issue 1, pp. 14-25.

8. Kulyk, p. (2013). Finansowe wsparcie rolnictwa w krajach o roznym poziomie rozwoju gospodarczego (Financial support to agriculture in countries at different levels of economic development). Wydawnictwo UE w Poznaniu, Poznan, pp. 177-182.

9. OECD (2016). PSE Manual. Retrieved: http://www.oecd.org/tad/agricultural-policies/psemanual.htm. Access: 20.01.2018, pp. 194.

10. OECD (2017). Agricultural Policy Monitoring and Evaluation. Retrieved: http://www.oecdilibrary.org/agriculture-and-food/agricultural-policy-monitoring-and-evaluation-2017_agr_pol-2017-en. Access: 23.01.2018, pp. 176.

11. Olper, A. (2001). Determinants of Agricultural Protection: The Role of Democracy and Institutional Setting. Journal of Agricultural Economics, Volume 52, Issue 2, pp. 75-92.

12. Pawlak, K. (2017). Znaczenie wymiany bilateralnej w handlu zagranicznym produktami rolno-spozywczymi UE i USA (The importance of the bilateral turnover to the EU and the US foreign trade in agri-food products). Zeszyty Naukowe Szkoly Glownej Gospodarstwa Wiejskiego w Warszawie - Problemy rolnictwa swiatowego, Volume 17(XXXII), Issue 2, pp. 199-210.

13. Poczta-Wajda, A. (2013). Measuring Domestic Agricultural Support in Developed Countries in the Light of the WTO Regulations. Wies i rolnictwo, Volume 1(158), pp. 44-58.

14. Poczta-Wajda, A. (2014). Assistance to Agriculture in Countries of a Different Development Level and Trends in World Trade with Agricultural Products. Annals of The Polish Association of Agricultural and Agribusiness Economists, Volume XVI, Issue 6, pp. 403-408.

15. Poczta-Wajda, A. (2017). Polityka wspierania rolnictwa a problem deprywacji dochodowej rolnikow w krajach o roznym poziomie rozwoju (The policy of agricultural support and the problem of farmer's income deprivation in countries at different levels of economic development). Wydawnictwo Naukowe PWN, Warszawa, pp. 43-45.

16. Producer and Consumer Support Estimates Database (2018). Retrieved: http://stats.oecd.org/. Access: 20.01.2018.

17. Prus, P., Drzazdzynska, K. (2017). Farmers' Assessment of Training Services and the Impact of Agricultural Advisory on Selected Developmental Factors Affecting Farming. Economic Science for Rural Development, Proceedings of the International Scientific Conference, Latvia University of Agriculture, Jelgava, No. 44, pp. 338-344. 
18. Reed, M.R. (2001). International Trade in Agricultural Products. Prentice Hall, Upper Saddle River, New Jersey, pp. 235.

19. Reiljan, J., Hinrikus, M., Ivanov, A. (2000). Key Issues in Defining and Analysing the Competitiveness of a Country. University of Tartu Economics and Business Administration Working Paper No. 1.

Retrieved: https://papers.ssrn. com/sol3/papers.cfm?abstract_id=418540, Access: 20.01.2018, pp. 37-39.

20. Swinnen, J.F.M., de Gorter, H., Rausser, G.C., Banerjee, A.N. (2000). The political economy of public research investment and commodity policies in agriculture: an empirical study. Agricultural Economics, Volume 22, pp. 111-122.

21. Tangermann, S. (2004). Agricultural Policies in OECD Countries 10 Years after the Uruguay Round: How Much Progress? In: Agricultural Policy Reform and the WTO - Where Are We Heading?, G. Anania, M.E. Bohman, C.A. Carter, A.F. McCalla (eds.). Edward Elgar, Cheltenham (UK) and Northampton (MA), pp. 15-42.

22. UNCTADstat (2018).

Retrieved: http://unctadstat.unctad.org/wds/ReportFolders/reportFolders.aspx?sCS_Chosen Lang=en. Access: 20.01.2018.

23. Van Duren, E., Martin, L., Westgren, R. (1991). Assessing the Competitiveness of Canada's Agrifood Industry. Canadian Journal of Agricultural Economics, Volume 39, Issue 4, pp. 727-738. 